Italy, Germany and Spain" (p. 149) ; that their kinship structure gives "the distinct impression of a double descent system" (p. 134) ; that the "sedent. ary women of Metlili go without trousers as a rule" (p. 208).

The book falls between two stools. It has far too many 'scientific' facts of this sort to make it a successful travel book ; on the other hand, there are far too many theories and insufficient supporting data to make it acceptable to anthropologists, archæologists or historians. Human geographers, however, should find it very useful, for it answers their need for a descriptive summary of the peoples of the Central and Western Sahara which is both up to date and accurate, and which takes care to distinguish between fact and fantasy. That the latter still occupies so much space is not a reflexion on Mr. Brigga's scholarship but on the weakness of anthropological fieldwork in this part of Africa. One could have wished, however, that he could have spent less of his twelve years of study in "threshing and winnowing all the Saharan literature that he could lay his hands on", and more time in field research among the Chamba and other representative communities.

The book is supported by two very inadequate sketch maps, thirty-three good plates and an impressive bibliography.

G. I. JoNES

\section{THE ECOLOGY OF AFRICAN GAME}

Wild Life in an African Territory

By Dr. F. Fraser Darling. (A Study made for the Game and Tsetse Control Department of Northern Rhodesia.) Pp. viii + 160. (London : Oxford University Press, 1960.) 25s. net.

$\mathrm{T}$ HIS book is primarily a report of a survey carried out by the author in Northern Rhodesia, with the object of examining the present status of the wild African game, the natural vegetation where it survives and the problems involved in the conservation of wild Nature in this territory. Much of the book is thus an account of the jourmeys undertaken and the terrain examined, followed by an ecological description of the vegetation and the habitats. The book concludes with an account of the measures of nature conservation already undertaken by the Government, and with recommendations for future action. There are, in addition, three appendixes, a directive on wild-life conservation issued by Sir Evelyn Baring as governor of Kenya, an official circular issued to all provincial commissioners in Northern Rhodesia on the same subject, and finally, a paper dealing with the status of the more important ungulates in Northern Rhodesia.

These materials are largely matters of record, though they give an excellent idea of the present condition of the country, and are valuable as a record and for comparison with such earlier data as are available.

In many ways the most interesting part of the book is the relation of this material to the underlying philosophy, and to the reflexions and observations embodied in the introduction and the middle chapters in which the ecology of African biological communities is discussed. Here the author draws freely on his wide experience to generalize. His view is that many of the existing habitats and biological com- munities in undeveloped Africa represent ecological climaxes which yield the maximum biological production possible under the difficult climatic and ancient soil conditions prevalent. This is mainly because the organisms present include a multitude of highly adapted plants and animals, the diversity of habit and function of which exploits to the full every variety of ecological niche. It follows that $a$ disturbance, and especially a simplification, of the ecological system (such as follow human 'development') is almost certain to lead to degradation of production and to site deterioration. There is therefore a case for maintaining the existing habitats and wild-life systems until further inquiry may disclose methods of land-use which can be fully equated with the natural systems already existing.

Dr. Darling applies this generalization to the particular problem involved in the conservation of the ungulate African animals and their habitats, including the human societies involved in his treatment of this eco-system. He considers that the game can be conserved and also used to give an adequate supply of protein food for Africans in the territory and this, rather than known alternative forms of land-use, offers the best prospect of preserving rather unstable habitats and also perhaps of permitting time for the development of the primitive human social systems. He has succeeded in integrating his material so well as to give a valuable picture of the background and the relation between social life, land-use and ecology in the still savage parts of Africa. Thus the book is an important and useful illustration of the new scientific approach to these problems of wild-life management as well as to the ecology of land-use. W. H. Pearsall

\section{KINETIC THEORY OF GASES}

\section{Elements of the Kinetic Theory of Gases}

By Prof. E. A. Guggenheim. (International Encyclopedia of Physical Chemistry and Chemical Physics. Topic 6: The Kinetic Theory of Gases, Vol. 1.) Pp. xii +92 . (London and New York: Pergamon Press, 1960.) 17s. 6d.

HHIS is the first part of the Encyclopedia of Physical Chemistry and Chemical Physics to be published. It leads us to expect an outstanding work.

Treatments of the kinetic theory of gases have tended to fall into two classes: there are the comprehensive, detailed and somewhat involved accounts which are concerned to be rigorous, regardless of complexity, and, on the other hand, there are simple, approximate accounts, frequently using unsatisfactory assumptions. Elements of the Kinetic Theory of Gases seems likely to make a wide appeal to readers who find neither of the two classes satisfactory.

A skilful mathematical formulation of basic kinetic phenomena leads to treatments of successive topics which are both incisive and concise. Clarity is furthered still more by the organization of the material into virtually self-contained, short chapters. The result is that the reader is continually struck by the power of essentially simple procedures which penetrate to the core of a problem, as, for example, in the derivation of Maxwell's distribution law. Again, collision-rates are considered with rigour but without complexity. Simplicity is not shunned even where 